\title{
PENGARUH MODEL PEMBELAJARAN DISCOVERY LEARNING TERHADAP HASIL BELAJAR SISWA PADA MATERI POKOK LISTRIK DINAMIS KELAS X SEMESTER II SMA NEGERI 11 MEDAN T.P 2014/2015
}

\author{
Henny Rukmanasari Hasibuan*) dan Purwanto**) \\ (Prodi Pendidikan Fisika FMIPA Unimed) \\ henny.rukmana1993@gmail.com \\ *) Mahasiswa Pendidikan Fisika Unimed \\ **) Dosen Fisika Unimed
}

\begin{abstract}
ABSTRAK
Penelitian ini bertujuan untuk mengetahui pengaruh model pembelajaran discovery learning terhadap hasil belajar siswa kelas X pada materi pokok Listrik Dinamis. Jenis penelitian ini adalah quasi experiment. Populasi dalam penelitian adalah seluruh siswa kelas $\mathrm{X}$ yang terdiri dari 8 kelas. Pengambilan sampel dilakukan dengan cara cluster random sampling dengan mengambil 2 kelas secara acak yaitu kelas X-5 sebagai kelas eksperimen dan kelas X-6 sebagai kelas kontrol. Instrumen yang digunakan adalah tes hasil belajar yang telah divalidasi dalam bentuk pilihan berganda sebanyak 20 soal. Hasil penelitian diperoleh nilai rata-rata pretes kelas eksperimen 33,06 dan kelas kontrol 32,78. Kemudian diberikan perlakuan yang berbeda, kelas eksperimen dengan model pembelajaran discovery learning dan kelas kontrol dengan model pembelajaran konvensional. Setelah pembelajaran selesai diberikan, diperoleh postes dengan nilai rata-rata kelas eksperimen 75,69 dan kelas kontrol 69,86. Hasil uji t dengan taraf signifikasi 0,05 bahwa secara signifikan ada perbedaan akibat pengaruh model pembelajaran discovery learning terhadap hasil belajar siswa pada materi pokok Listrik Dinamis di kelas X.
\end{abstract}

Kata kunci : model pembelajaran discovery learning dan hasil belajar siswa.

\begin{abstract}
This research aimed to know the effect of discovery learning model on students learning outcomes in the subject matter dynamical electricity in class $X$. The type of research was quasi-experimental. The population were the tenth grade students consisting of 8 classes. The samples collection done by means of cluster of random sampling by taking 2 class at random that is class $X-5$ as experiment class and class X-6 as control class. The instruments used were test of learning outcomes that have been validated in the form of option as much as 20 questions. The research result obtained average value of experiment pretest class 33,06 and the control class 32,78. Then given different treatment, experiment class with discovery learning and control class with conventional of models. After learning is completed, obtained postest the average value of experiment class 75,69 and control class 69,86. The results of t one party with the level significance in 0,05 obtained there is difference of students' learning outcomes due to the effect of discovery learning in the subject matter listrik dinamis in class $X$.
\end{abstract}

Keywords: Discovery learning model, and learning outcome. 


\section{PENDAHULUAN}

Pendidikan

merupakan kebutuhan yang penting bagi setiap manusia. Tanpa pendidikan seseorang akan sulit untuk menyesuaikan diri dengan lingkungan dan tidak dapat berfungsi maksimal dalam kehidupan masyarakat. Pendidikan saat ini sering mengalami perkembangan yang sangat pesat. Berbagai cara atau metode baru yang telah diperkenalkan serta digunakan supaya pembelajaran menjadi lebih bermakna.

Pendidikan fisika merupakan salah satu kajian bidang dari Ilmu Pengetahuan Alam (IPA) yang mempelajari peristiwa dan gejalagejala yang terjadi di alam semesta sehingga fisika dapat dikatakan sebagai pondasi teknologi yang cukup beralasan untuk diberikan kepada siswa sebagai bekal dalam menghadapi hidup di masa mendatang. Sebagai bagian dari IPA maka hakikat fisika dapat ditinjau dan dipahami melalui hakikat sains yaitu proses sains dan produk sains. Produk sains dapat berupa fakta, konsep, prinsip atau hukum dan teori. Sedangkan proses sains berupa langkah-langkah yang harus ditempuh oleh para ilmuwan (saintis) untuk melakukan penyelidikan dalam rangka memperoleh penjelasan tentang gejala-gejala alam. Pendidikan dilaksanakan melalui kegiatan pembelajaran, baik di sekolah maupun diluar sekolah. Di sekolah, lembaga pendidikan diharapkan mampu untuk mengembangkan keterampilan berfikir siswa.

Mutu pendidikan sains khususnya fisika di berbagai jenjang pendidikan di Indonesia masih rendah. Hal ini sejalan dengan Laporan United Nations Development Programme (UNDP) 2014, mengungkapkan bahwa peringkat Indonesia dibidang pendidikan pada tahun 2014 tidak berubah pada posisi 108 dari 187 dari tahun sebelumnya. Berdasarkan data The Learning Curve Pearson tahun 2014 juga menunjukkan bahwa Indonesia menempati posisi ke-40 dengan indeks rangking dan nilai secara keseluruhan yakni -1,84, sementara pada kategori kemampuan kognitif indeks rangking Indonesia dengan nilai 2,11. Ini menunjukkan tidak adanya perbaikkan signifikan yang dibuat Indonesia dalam perbaikan sumber daya manusianya (tribunnews.com,15 Maret 2015).

Rendahnya kualitas pendidikan yang dihasilkan tidak terlepas dari berbagai faktor di antaranya pengemasan pembelajaran, proses pembelajaran fisika yang berlangsung masih berorientasi pada buku teks dan ketercapaian kurikulum dengan didominasi oleh pembelajaran langsung. Pada proses pembelajaran suasana kelas cenderung teachercentered sehingga siswa cenderung pasif dalam mengikuti pembelajaran, kurang memiliki inisiatif di kelas, dan kurang kreatif dalam berpikir. Proses pembelajaran di dalam kelas diarahkan kepada kemampuan anak untuk menghafal informasi, tanpa dituntun untuk memahami informasi yang diingatnya untuk dihubungkan dengan kehidupan sehari-hari.

Berdasarkan hasil observasi yang telah dilakukan di kelas X SMA Negeri 11 Medan tahun pelajaran 2013/2014 menunjukan bahwa nilai rata-rata ulangan harian pelajaran Fisika pada materi pokok Listrik Dinamis yang diperoleh adalah 60 . Nilai tersebut masih dikatakan rendah dan belum memenuhi nilai Kriteria Ketuntasan Maksimal (KKM) yaitu 
75. Dari angket yang disebar kepada 36 orang siswa menunjukkan bahwa $75 \%$ siswa tidak menyukai pelajaran fisika, 55\% siswa mengatakan proses pembelajaran berlangsung dengan mencatat dan mengerjakan soal/latihan dan hanya 5\% siswa mengatakan bahwa proses pembelajaran di kelas berlangsung dengan melakukan eksperimen, hal ini diperkuat dengan hasil wawancara dengan salah satu guru fisika di SMA Negeri 11 Medan, mengatakan bahwa kurang memadainya alat-alat yang ada di dalam laboratorium fisika menyebabkan eksperimen dalam proses pembelajaran jarang dilakukan. Kurangnya minat belajar menyebabkan kurang aktifnya siswa dalam proses pembelajaran dikarenakan siswa kurang terlibat secara langsung dalam penyelesaian masalah sehingga hasil belajar siswa rendah.

Hal ini diperkuat oleh Hosnan (2014) yang mengatakan bahwa proses pembelajaran yang dilaksanakan haruslah terhindar dari dominasi guru yang cenderung menimbulkan sikap pasif anak didik. Seharusnya proses pembelajaran yang dilaksanakan dapat mendorong sikap siswa sendiri dan guru perlu mengupayakan agar siswa dapat terlibat langsung secara aktif dalam pembelajaran, baik individual maupun kelompok.

Menurut teori konstruktivis (Budiningsih, 2012) mengatakan bahwa pengetahuan bukanlah suatu barang yang dapat dipindahkan dari pikiran seseorang yang telah memiliki pengetahuan kepada pikiran seseorang yang belum memiliki pengetahuan tersebut. Dari kedua pendapat tersebut dapat ditemukan suatu konsep pembelajaran yang dapat membuat siswa terlibat langsung secara aktif dalam pembelajaran, sehingga pembelajaran tersebut dapat bertahan lama di dalam ingatan siswa dan lebih bermakna. Maka dalam proses pembelajaran guru harus melibatkan proses berpikir dan dapat membangun suasana dialogis proses tanya jawab terus menerus untuk memperbaiki dan meningkatkan kemampuan berfikir siswa, yang pada gilirannya kemampuan berfikir itu dapat membantu siswa untuk memperoleh pengetahuan yang mereka konstruksi sendiri.

Berdasarkan pertimbangan tersebut dan masalah-masalah yang dihadapi di SMA Negeri 11 Medan, maka salah satu upaya yang dilakukan untuk meningkatkan pembelajaran fisika adalah dengan mengembangkan model discovery learning. Menurut Hosnan (2014), pembelajaran discovery learning adalah suatu model untuk mengembangkan cara belajar siswa aktif dengan menemukan sendiri, menyelidiki sendiri, maka hasil yang akan diperoleh akan setia dan tahan lama dalam ingatan, tidak akan mudah dilupakan siswa. Dengan belajar penemuan anak-anak juga bisa belajar berpikir analisis dan mencoba memecahkan sendiri masalah yang dihadapi.

Model pembelajaran discovery learning telah banyak dibuktikan melalui penelitian, diantaranya Indarti, dkk (2014) menyimpulkan bahwa kemampuan memecahkan masalah siswa yang pembelajarannya dengan menggunakan model discovery learning lebih baik daripada menggunakan model pembelajaran konvensional. Hasil penelitian Widiadnyana, dkk (2014) menyimpulkan bahwa terdapat perbedaan pemahaman konsep IPA 
dan sikap ilmiah antara siswa yang belajar menggunakan model discovery learning dengan siswa yang belajar menggunakan model pengajaran langsung.

Adapun yang menjadi tujuan penelitian adalah untuk mengetahui pengaruh model pembelajaran discovery learning terhadap hasil belajar siswa pada materi pokok listrik dinamis kelas X SMA Negeri 11 Medan T.P. 2014/2015.

\section{METODE PENELITIAN}

Jenis penelitian ini adalah quasi experiment dengan two group pretesposttest design. Populasi dalam penelitian adalah seluruh siswa kelas $X$ SMA Negeri 11 Medan T.P 2014/2015 yang terdiri atas 8 kelas. Pengambilan sampel dilakukan dengan teknik sampel kelas acak (cluster random sampling), diambil 2 kelas yaitu kelas X-5 sebagai kelas eksperimen diajarkan model discovery learning dan kelas X-6 sebagai kelas kontrol diajarkan model pembelajaran konvensional.

Alat pengumpul data dalam penelitian ini adalah tes hasil belajar berbentuk pilihan berganda dengan jumlah 25 soal yang sudah divalidasikan. Tes hasil belajar ini digunakan untuk mengetahui kemampuan siswa pada tingkat kognitif.

$$
\text { Uji hipotesis yang }
$$

dikemukakan dilaksanakan dengan membandingkan rata-rata skor hasil belajar yang dicapai baik kelompok eksperimen maupun kelompok kontrol. Data yang diperoleh ditabulasikan kemudian dicari rataratanya. Sebelum dilakukan penganalisisan data, terlebih dahulu ditentukan skor masing-masing kelompok sampel lalu dilakukan pengolahan data dengan langkahlangkah sebagai berikut:

a) Menghitung nilai rata-rata dan simpangan baku

b) Uji normalitas dengan menggunakan uji lilliefors

c) Uji homogenitas dengan menggunakan uji kesamaan dua varians

Uji normalitas dan uji homogenitas dimaksudkan sebagai prasyarat melakukan uji hipotesis jika populasi terdistribusi normal dan homogen.

d) Pengujian hipotesis dengan menggunakan uji t

Uji hipotesis dua pihak digunakan untuk mengetahui kesamaan kemampuan awal siswa pada kedua kelompok sampel dan uji hipotesis satu pihak digunakan untuk mengetahui pengaruh dari suatu perlakuan yaitu model pembelajaran diskoveri terhadap hasil belajar siswa.

\section{HASIL DAN PEMBAHASAN Hasil Penelitian}

Adapun hasil penelitian ini adalah bahwa nilai rata-rata pretes eksperimen sebesar 33,06 dan nilai rata-rata pretes kelas kontrol sebesar 32,78 seperti yang ditunjukkan pada Tabel 1.

Tabel 1. Data pretes kelas eksperimen

\begin{tabular}{|c|c|c|c|}
\hline Nilai & Frekuensi & $\begin{array}{c}\text { Rata- } \\
\text { rata }\end{array}$ & $\begin{array}{c}\text { Standar } \\
\text { Deviasi }\end{array}$ \\
\hline $10-17$ & 2 & \multirow{7}{*}{33,06} & \multirow{7}{*}{10,30} \\
\hline $18-25$ & 8 & & \\
\hline 26-33 & 6 & & \\
\hline $34-41$ & 14 & & \\
\hline $42-49$ & 3 & & \\
\hline $50-57$ & 3 & & \\
\hline \multicolumn{2}{|c|}{$\sum=36$} & & \\
\hline
\end{tabular}

Distribusi frekuensi data pretes siswa kelas eksperimen lebih jelasnya divisualisasikan dalam 
diagram batang pada Gambar 1 . Terlihat bahwa kurva frekuensi yaitu model positif, hal tersebut terjadi karena soal tes yang terlalu sulit sehingga banyak peserta yang mendapat nilai buruk.

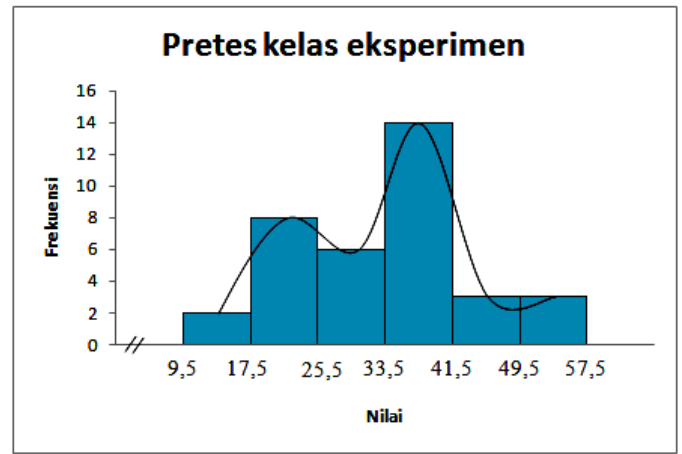

Gambar 1. Diagram batang data pretes siswa kelas eksperimen

Hasil pretes kelas kontrol memperoleh nilai rata-rata 32,78 . Data hasil pretes tersebut dalam bentuk distribusi frekuensi yang ditunjukkan pada Tabel 2.

Tabel 2. Data pretes kelas kontrol

\begin{tabular}{|c|c|c|c|}
\hline Nilai & Frekuensi & $\begin{array}{l}\text { Rata } \\
\text {-rata }\end{array}$ & $\begin{array}{l}\text { Standar } \\
\text { Deviasi }\end{array}$ \\
\hline $10-16$ & 5 & \multirow{7}{*}{32,78} & \multirow{7}{*}{12,39} \\
\hline $17-23$ & 3 & & \\
\hline 24-30 & 7 & & \\
\hline $31-37$ & 6 & & \\
\hline $38-44$ & 6 & & \\
\hline $45-51$ & 9 & & \\
\hline & 36 & & \\
\hline
\end{tabular}

Distribusi frekuensi data pretes siswa kelas kontrol lebih jelasnya divisualisasikan dalam diagram batang pada Gambar 2 . Terlihat bahwa kurva frekuensi yaitu model positif, hal tersebut terjadi karena soal tes yang terlalu sulit sehingga banyak peserta yang mendapat nilai buruk.

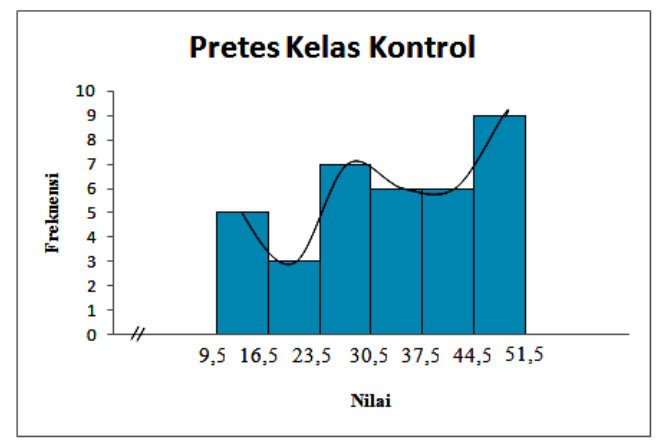

Gambar 2. Diagram batang data pretes siswa kelas kontrol

Hasil uji normalitas data pretes pada kelas eksperimen dan kontrol masing-masing diperoleh $\mathrm{L}_{\text {hitung }}=0,1190<\mathrm{L}_{\text {tabel }}=0,1477$ dan $\mathrm{L}_{\text {hitung }}=0,1060<\mathrm{L}_{\text {tabel }}=0,1477$. Hasil uji homogenitas pada data pretes diperoleh $F_{\text {hitung }}=1,45<\mathrm{F}_{\text {tabel }}$ $=1,75$. Berdasarkan hasil kedua pengujian ini disimpulkan bahwa populasi berdistribusi normal dan homogen sehingga layak dilakukan uji hipotesis dua pihak dengan hasil uji hipotesis seperti pada Tabel 3 .

Tabel 3. Ringkasan Perhitungan Uji Hipotesis Kemampuan Pretes

\begin{tabular}{llllll}
\hline No & $\begin{array}{l}\text { Data } \\
\text { Kelas }\end{array}$ & $\begin{array}{c}\text { Nilai } \\
\text { Rata- } \\
\text { rata }\end{array}$ & $\mathbf{t}_{\text {hitung }}$ & $\mathbf{t}_{\text {tabel }}$ & $\begin{array}{c}\text { Kesimpu } \\
\text { lan }\end{array}$ \\
\hline 1. & $\begin{array}{l}\text { Pretes } \\
\text { kelas } \\
\text { eskperi } \\
\text { men }\end{array}$ & 33,06 & & & \\
\cline { 1 - 2 } & & 0,104 & 1,997 & $\begin{array}{c}\text { Ho } \\
\text { diterima }\end{array}$ \\
& $\begin{array}{l}\text { Pretes } \\
\text { kelas } \\
\text { kontrol }\end{array}$ & 32,78 & & & \\
\hline
\end{tabular}

Perolehan nilai rata-rata postes setelah diberikan perlakuan pembelajaran dengan model pembelajaran diskoveri pada kelas eksperimen sebesar 75,69 seperti yang ditunjukkan oleh Tabel 4 . 
Tabel 4. Data postes kelas eksperimen

\begin{tabular}{|c|c|c|c|}
\hline Nilai & Frekuensi & $\begin{array}{c}\text { Rata- } \\
\text { rata }\end{array}$ & $\begin{array}{c}\text { Standar } \\
\text { Deviasi }\end{array}$ \\
\hline $55-61$ & 4 & & \\
\cline { 1 - 2 } $62-69$ & 3 & & \\
\hline $70-77$ & 13 & \multirow{3}{*}{75,69} & \multirow{2}{*}{9,50} \\
\cline { 1 - 2 } $78-85$ & 13 & & \\
\cline { 1 - 2 } $86-93$ & 2 & & \\
\cline { 1 - 2 } $94-101$ & 1 & & \\
\cline { 1 - 2 } \multicolumn{2}{|r|}{$\sum=36$} & & \\
\hline
\end{tabular}

Distribusi frekuensi data postes siswa kelas eksperimen lebih jelasnya dapat divisualisasikan dalam diagram batang hasil postes siswa kelas eksperimen pada Gambar 3. Terlihat bahwa kurva frekuensi yaitu model negatif, hal tersebut terjadi karena soal tes yang terlalu mudah sehingga banyak peserta yang mendapat nilai baik.

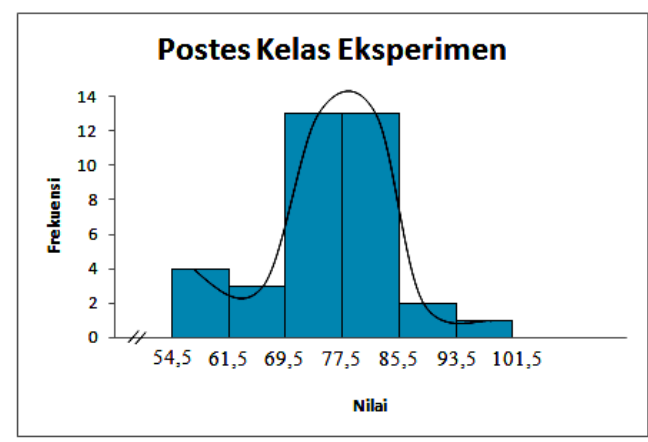

Gambar 3. Diagram batang data postes siswa kelas eksperimen

Data hasil belajar siswa kelas kontrol memperoleh nilai rata-rata postes sebesar 69,86. Hasil postes kelas kontrol dalam bentuk distribusi frekuensi tertera pada Tabel 5 .

Tabel 5. Data postes kelas kontrol

\begin{tabular}{|c|c|c|c|}
\hline Nilai & Frekuensi & $\begin{array}{c}\text { Rata- } \\
\text { rata }\end{array}$ & $\begin{array}{c}\text { Standar } \\
\text { Deviasi }\end{array}$ \\
\hline $50-56$ & 5 & & \\
\cline { 1 - 2 } $57-63$ & 6 & \multirow{2}{*}{69,86} & \multirow{2}{*}{9,17} \\
\hline $64-70$ & 6 & & \\
\hline $71-77$ & 12 & & \\
\cline { 1 - 2 } & \multicolumn{2}{|c}{} \\
\cline { 1 - 2 }
\end{tabular}

\begin{tabular}{|c|c|}
\hline $78-84$ & 3 \\
\hline $85-91$ & 4 \\
\hline & \\
\hline
\end{tabular}

Distribusi frekuensi data postes siswa kelas kontrol lebih jelasnya dapat divisualisasikan dalam diagram batang hasil postes siswa kelas kontrol pada Gambar 4. Terlihat bahwa kurva frekuensi yaitu model negatif, hal tersebut terjadi karena soal tes yang terlalu mudah sehingga banyak peserta yang mendapat nilai baik.

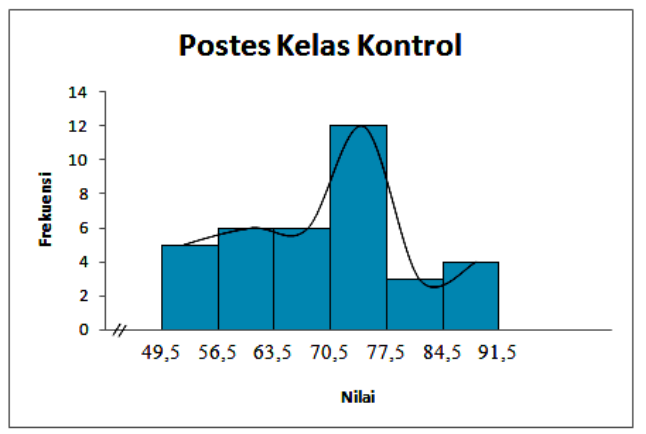

Gambar 4. Diagram batang data postes siswa kelas kontrol

Hasil uji normalitas data postes pada kedua kelas masingmasing diperoleh $\mathrm{L}_{\text {hitung }}=0,1042<$ $\mathrm{L}_{\text {tabel }}=0,1477$ dan $\mathrm{L}_{\text {hitung }}=0,1399<$ $\mathrm{L}_{\text {tabel }}=0,1477$. Hasil uji homogenitas pada data postes diperoleh $\mathrm{F}_{\text {hitung }}=$ $1,10<\mathrm{F}_{\text {tabel }}=1,75$. Berdasarkan hasil kedua pengujian ini disimpulkan bahwa populasi berdistribusi normal dan homogen sehingga layak dilakukan uji hipotesis satu pihak dengan hasil uji hipotesis seperti pada Tabel 6.

Tabel 6. Ringkasan Perhitungan Uji Hipotesis Kemampuan Postes

\begin{tabular}{cccccc}
\hline No & $\begin{array}{c}\text { Data } \\
\text { Kelas }\end{array}$ & $\begin{array}{c}\text { Nilai } \\
\text { Rata- } \\
\text { rata }\end{array}$ & $\mathbf{t}_{\text {thitung }}$ & $\mathbf{t}_{\text {tabel }}$ & $\begin{array}{c}\text { Kesimpu } \\
\text { lan }\end{array}$ \\
\hline 1. & $\begin{array}{l}\text { Postes } \\
\text { kelas }\end{array}$ & 75,69 & 2,19 & 1,67 & $\begin{array}{c}\mathrm{H}_{\mathrm{a}} \\
\text { diterima }\end{array}$ \\
\hline
\end{tabular}




\begin{tabular}{lll}
\hline \multicolumn{3}{c}{$\begin{array}{l}\text { eksperi } \\
\text { men }\end{array}$} \\
\hline 2. & $\begin{array}{l}\text { Postes } \\
\text { kelas } \\
\text { kontrol }\end{array}$ \\
\hline
\end{tabular}

\section{Pembahasan}

Hasil belajar siswa untuk kelas eksperimen yang diajar dengan model pembelajaran discovery learning dengan jumlah siswa 36 orang memperoleh nilai rata-rata postes sebesar 75,69 dengan nilai tertinggi adalah 95 dan nilai terendah adalah 55. Sedangkan hasil belajar kelas kontrol yang diajar dengan model pembelajaran konvensional dengan jumlah siswa 36 orang memperoleh nilai rata-rata postes sebesar 69,86 dengan nilai tertinggi adalah 90 dan nilai terendah adalah 50. Hasil penelitian menunjukkan bahwa model pembelajaran discovery learning lebih baik dibandingkan dengan model pembelajaran konvensional.

Hasil penelitian menunjukkan bahwa ada perbedaan akibat pengaruh model pembelajaran discovery learning daripada model pembelajaran konvensional. Hal ini diperkuat dengan data postes di kelas eksperimen memperoleh nilai ratarata sebesar 75,69 sedangkan data postes di kelas kontrol memperoleh nilai rata-rata sebesar 69,86. Dimana $t_{\text {hitung }}$ untuk kelas eksperimen dan kelas kontrol adalah 2,19 dan $t_{\text {tabel }}$ adalah 1,67 maka $t_{\text {hitung }}>t_{\text {tabel }}$ dengan $\alpha=0,05 \quad$ sehingga diperoleh kesimpulan bahwa ada perbedaan akibat pengaruh model pembelajaran discovery learning terhadap hasil belajar siswa. Ini membuktikan bahwa ada perbedaan akibat pengaruh model pembelajaran discovery learning daripada model pembelajaran konvensional.

\section{KESIMPULAN DAN SARAN}

Kesimpulan ini didasarkan dari hasil analisis yang dilakukan dalam penelitian ini diperoleh kesimpulan rata-rata hasil belajar postes siswa pada kelas eksperimen yang diajarkan dengan model pembelajaran discovery learning telah memenuhi KKM yaitu sebesar 75,69 yang tergolong tuntas. Sedangkan rata-rata hasil belajar pretes siswa pada kelas kontrol yang diajarkan dengan model pembelajaran konvensional belum memenuhi KKM yaitu sebesar 69,86 yang tergolong tidak tuntas. Hasil uji hipotesis memberikan nilai $t_{\text {hitung }}=2,19$ dan $\mathrm{t}_{\text {tabel }}=1,67$ dengan $\mathrm{dk}=70$ dan taraf signifikan $\alpha=0,05$, maka $t_{\text {hitung }}>t_{\text {tabel, }}$ menunjukkan bahwa ada perbedaan akibat pengaruh model pembelajaran discovery learning daripada model pembelajaran konvensional terhadap hasil belajar siswa pada materi pokok Listrik Dinamis di kelas X semester II SMA Negeri 11 Medan T.P 2014/2015.

Saran bagi peneliti selanjutnya yang ingin melakukan penelitian dengan menggunakan model pembelajaran discovery learning disarankan lebih memperhatikan pengorganisasian kelompok belajar dan membimbing siswa selama bekerja dalam kelompok. Kepada peneliti selanjutnya hendaknya mengajarkan siswa terlebih dahulu cara menggunakan alat ukur listrik dengan benar sehingga ketika eksperimen dilakukan siswa sudah dapat melakukan proses mengukur dengan alat ukur listrik tersebut. 
DAFTAR PUSTAKA

Budiningsih, C.A., (2012), Belajar dan Pembelajaran, PT Rineka Cipta, Jakarta.

Hosnan, M., (2014), Pendekatan Saintifik dan Kontekstual dalam Pembelajaran Abad 21 (Kunci Sukses Implementasi Kurikulum 2013), Ghalia Indonesia, Bogor.

Indarti., Suyudi, A., dan Yogihati, C.I., (2014), Pengaruh Model Discovery Learning terhadap Kemampuan Memecahkan Masalah Siswa Kelas X SMA N 8 Malang Universitas Negeri Malang, Jurnal Fisika, Universitas Negeri Malang, Malang.

Widiadnyana, I.W., Sadia, I.W., dan Suastra, I.W., (2014), Pengaruh Model Discovery Learning terhadap Pemahaman Konsep IPA dan Sikap Ilmiah Siswa SMP, Jurnal Program Universitas Pendidikan Ganesha Vol 4, Singaraja. 